\title{
O FUTURO DA MOBILIDADE URBANA E O CASO UBER
}

\section{THE FUTURE OF URBAN MOBILITY AND THE UBER CASE}

\section{Cláudio Ari Mello ${ }^{1}$}

\section{Resumo}

O ensaio examina as questões jurídicas mais relevantes do caso envolvendo a entrada do modelo da empresa UBER no sistema de transporte urbano. O estudo conclui que a lei da política nacional de mobilidade urbana (Lei n. 12.587/2012) instituiu o serviço público de transporte individual de passageiros como um gênero, do qual o tradicional serviço de táxi é apenas uma classe. A lei permite a existência de serviços alternativos de transporte individual de passageiros, tal como o modelo da UBER. Entretanto, por tratar-se de um serviço de utilidade pública, o Estado detêm o poder e o dever de organizar, disciplinar e controlar a prestação do serviço, inclusive mediante a criação de mecanismos de regulação de entrada.

Palavras-chave: Direito urbanístico; cidade sustentável; planejamento urbanístico; mobilidade urbana; transporte urbano.

\begin{abstract}
The essay examines the most relevant legal questions related to the rising of the UBER model in the urban transport system. The study concludes that the act of national policy of urban mobility (Lei n. 12.587/2012) has instituted the public service of individual passengers transport as a genre, being the traditional service of taxi only a class. The act allows alternative models of services of individual passengers transport, such as the UBER model. However, to the extent that it is a service of public utility, it can and must be organized, regulated and controlled by the Government, even with the creation of entry regulation mechanisms.
\end{abstract}

Keywords: Urban Law; sustainable cities; urban planning; urban mobility; urban transport.

\footnotetext{
${ }^{1}$ Professor de Teoria do Direito e Direito Constitucional nos cursos de graduação e mestrado em Direito do Centro Universitário Uniritter, Porto Alegre. Doutor em Teoria do Direito pela UFRGS, Mestre em Direito do Estado pela PUCRS. E-mail: claudio.ari@hotmail.com
} 


\section{INTRODUÇÃO}

A Constituição Federal de 1988 é ainda uma obra a ser compreendida. Elogiada e criticada com a mesma intensidade, acusada de atrasar o desenvolvimento do país e enaltecida por conter um desenho institucional que tem sido capaz de garantir a estabilidade democrática e permitir avanços sociais e culturais inéditos na história do Brasil, ela continua a surpreender aqueles que procuram encontrar no seu texto fundamentos normativos para promover transformações políticas e jurídicas na vida social brasileira.

Neste artigo, vamos explorar um exemplo das virtualidades positivas e surpreendentes da Constituição Federal. Nas últimas duas décadas, vimos emergir uma preocupação nos meios acadêmicos e institucionais em relação ao desenvolvimento sustentável das cidades e a compreensão da necessidade de elaborar uma teoria e uma prática da cidade justa. Uma teoria da cidade justa ${ }^{2}$ ou da cidade sustentável envolve pensar essa estrutura para muito além da sua realidade física ou material. Cidades são organismos complexos, onde a vida humana individual e as relações sociais acontecem na sua plenitude. Muito mais do que uma construção artificial, as cidades são o locus onde a experiência existencial completa do homem moderno efetivamente acontece.

Os constituintes de 1988 anteciparam-se à consolidação dessa preocupação acadêmica e institucional e dedicaram um capítulo do texto constitucional à "Política Urbana", regulada nos artigos 182 e 183. Não pretendemos aqui analisar os dispositivos inseridos neste capítulo da Constituição. Vamos tratar especificamente daquela que consideramos a mais importante diretriz normativa prevista na lei fundamental acerca da política urbana: o princípio da cidade sustentável ou da cidade justa. Não há, no texto dos dispositivos constitucionais referidos, nenhuma referência explícita a este princípio. Entretanto, ao enunciar, no caput do artigo 182, que a política de desenvolvimento urbano "tem por objetivo ordenar o pleno desenvolvimento das funções sociais da cidade e garantir o bem-estar de seus habitantes", parece claro que a Constituição instituiu um princípio jurídico a partir do qual ações públicas e privadas podem ser deduzidas com o objetivo de assegurar a promoção de uma cidade justa ou sustentável.

\footnotetext{
2 Sobre uma teoria política da cidade justa, ver Susan S. Fainstein, The Just City, Ithaca: Cornell University Press, 2011, Don Mitchell, The Right to the City: Social Justice and the Fight for Public Space, New York: The Guilford Press, 2003, e Neil Brenner, Peter Marcuse e Margit Mayer (editors), Cities for People, Not for Profit: Critical Urban Theories and the Right to the City, New York: Routledge, 2012. Sobre teorias da cidade, ver Marconi do Ó Catão, Civilizações Urbanas e Teorias da Cidade, Revista de Direito da Cidade, vol. 07, n. 01, p. 91-140.
}

Revista de Direito da Cidade, vol. 08, no 2. ISSN 2317-7721 pp.775-812 776 
Ao colocar no centro da "política constitucional de desenvolvimento urbano" (i) as funções sociais da cidade e (ii) o bem-estar de seus habitantes, é claro o enunciado permite concluir que estamos diante de um princípio normativo que tem como suporte uma compreensão humanista de cidade, ou seja, como o espaço político onde a existência humana individual e social se realiza na integralidade. Essa complexidade é, posteriormente, adotada, densificada e aperfeiçoada pelo Estatuto da Cidade, instituído pela Lei n. 10.257/2001, cujas diretrizes gerais não apenas acolhem explicitamente a referência ao princípio da cidade sustentável, elevada à categoria de direito (art. $2 \stackrel{2}{-}$ I), como incorpora toda a complexidade do conceito, incluindo no seu conteúdo os direitos à terra urbana, à moradia, ao saneamento ambiental, à infraestrutura urbana, ao transporte e aos serviços públicos, ao trabalho e ao lazer.

O conceito de política urbana é, evidentemente, muitidimensional. Uma política urbana que pretenda obter uma cidade justa ou sustentável precisa dar conta dos inúmeros e diversificados fatores que envolvem a existência humana individual e as relações sociais que se desenrolam no espaço urbano. Entre essas múltiplas dimensões encontra-se a mobilidade urbana, seguramente um dos aspectos que mais impactam o bem-estar e a qualidade de vida dos membros de uma comunidade urbana no mundo contemporâneo. Compreende-se, por isso, que o Estatuto da Cidade tenha dedicado alguns dispositivos para tratar do tema (art. 2ㅇ, I e V, e 3ㅇ, IV) e que tenha sido editada a Lei n. 12.587, de 3 de janeiro de 2012, que instituiu a Política Nacional de Mobilidade Urbana.

O artigo 10 da Lei n. 12.587 dispõe que a Política Nacional de Mobilidade Urbana é instrumento da "política de desenvolvimento urbano", e artigo 2 ㅇ dispõe que a PNMU tem por objetivo contribuir para o acesso universal à cidade, o fomento e a concretização das condições que permitam a efetivação dos princípios, objetivos e diretrizes da política de desenvolvimento urbano, por meio do planejamento e da gestão democrática do Sistema Nacional de Mobilidade Urbana. Ordenar a cidade para torná-la justa ou sustentável exige, pois, entre outras ações, disciplinar, dirigir e promover publicamente a mobilidade urbana, visando a garantir o bem-estar dos seus habitantes e as funções sociais da cidade.

Este ensaio é dedicado à discussão jurídica de um dos mais importantes e estimulantes cases da ordenação urbanística das cidades modernas contemporâneas: o surgimento de uma nova modalidade de transporte individual remunerado de passageiros, implantado pela empresa norte-americana UBER, que opera atualmente em centros urbanos de muitos países, inclusive no Brasil. Esse tipo de serviço de transporte foi tradicionalmente monopolizado pelo chamado "modal 
táxi". O sistema criado pela UBER desafia essa centenária tradição e parece realmente se colocar como um modelo que não apenas competirá com o sistema de táxi, como exigirá uma revisão do modo como a política de mobilidade urbana historicamente concebeu o transporte individual remunerado de passageiros nas cidades modernas. Ou seja, o modelo de transporte individual remunerado de passageiros operado por meio do novo modelo coloca em questão o futuro da mobilidade urbana nas cidades modernas.

O objetivo do ensaio é basicamente o de oferecer uma resposta juridicamente consistente ao problema da interpretação das normas jurídicas que podem ser invocadas para a regulação do tema. Não temos como propósito a análise das questões econômicas, políticas e culturais envolvidas na questão, embora reconheçamos a relevância desses aspectos para a compreensão global do problema. Partimos da premissa de que o chamado "caso UBER" tem se revelado como um dos mais complexos problemas de interpretação de normas jurídicas do direito público brasileiro dos últimos anos, o que é evidenciado pela multiplicidade de visões divergentes que vêm sendo produzidas por juristas acadêmicos e práticos do direito. O estudo que se segue é, portanto, essencialmente uma proposta de solução jurídica do problema por meio de uma interpretação responsável dos enunciados normativos relevantes para o caso.

\section{A NATUREZA ECONÔMICA DO SERVIÇO PRESTADO POR MEIO DA EMPRESA UBER}

A empresa UBER utiliza um aplicativo desenvolvido para aparelhos smartphones e tablets por meio do qual interliga usuários do aplicativo e motoristas de automóveis particulares que oferecem o serviço de transporte individual remunerado de passageiros. Proprietários de automóveis interessados em prestar esse tipo de serviço efetuam o seu credenciamento junto à empresa, mediante procedimento no qual devem comprovar o atendimento a um conjunto de exigências que englobam requisitos de ordem subjetiva, como a qualificação como motorista e a vida pregressa criminal, e requisitos de ordem objetiva, como a qualidade e o tempo de uso do veículo a ser empregado no serviço. Aceito o credenciamento pela empresa, os serviços do motorista cadastrado passam a ficar acessíveis ao público usuário. O sistema prevê que o motorista receberá o valor do serviço de transporte, descontado o percentual cobrado pela empresa pelo serviço de intermediação entre motorista e passageiro.

O usuário do aplicativo da UBER, por sua vez, inicialmente faz o download do programa em seu aparelho, informando seus dados pessoais e um número de cartão de crédito, e por meio dele solicita um motorista credenciado na empresa quando pretende usufruir do serviço de 
transporte individual remunerado de passageiros. O pagamento é feito através do cartão de crédito que o usuário habilitou no aplicativo da empresa. O serviço de transporte compreende pegar o passageiro no local solicitado e levá-lo até o destino previamente informado no próprio aplicativo. O valor a ser pago é calculado com base na distância do trajeto percorrido pelo motorista ao prestar o serviço de transporte.

O serviço prestado através do aplicativo UBER é muito similar ao tradicional serviço de transporte individual prestado por táxi. Essa semelhança não é nenhuma coincidência. Os relatos a respeito da origem da UBER revelam que seus fundadores, atuantes no famoso Vale do Silício, no Estado norte-americano da Califórnia, conceberam inicialmente o aplicativo e seu respectivo uso exatamente a partir de uma crítica à qualidade do serviço de táxi e da consequente iniciativa de criar uma alternativa ao táxi, mediante uma ferramenta moderna e mais ágil.

A semelhança entre o modal táxi e o serviço da empresa é evidente. Assim como o serviço prestado através do aplicativo UBER, o serviço de táxi também é essencialmente um serviço de transporte individual remunerado de passageiros. Por meio do táxi, um usuário do serviço é transportado de um determinado local até o destino desejado e paga um determinado valor, calculado com base na distância percorrida no trajeto do transporte.

Existem, contudo, diferenças importantes. O serviço de táxi possui diversas formas de acesso. Podemos tomar um táxi: (I) acenando para o taxista nas vias públicas (sistema de hailing), (II) dirigindo-nos até um ponto fixo de táxis (sistema de taxi rank), (III) telefonando para uma central telefônica que nos encaminha um táxi (sistema de taxi-booking) ou (IV) utilizando aplicativos para telefones celulares muito semelhantes ao aplicativo da UBER. Os serviços de transporte prestados por meio da UBER são diferentes das modalidades de serviço de táxi descritas em I, II e III. Por outro lado, são basicamente idênticos aos serviços prestados na modalidade IV.

Os serviços de táxi prestados por meio de aplicativos para smartphones também são acessados por usuários que necessitam efetuar previamente o download do respectivo programa e somente podem usar o serviço mediante o acesso ao aplicativo. Há, contudo, algumas diferenças entre os sistemas. Primeiro, o pagamento à empresa proprietária do aplicativo pode ser feito por meio de cartão de crédito previamente cadastrado no programa, mas pode ser feito em dinheiro ou cartão de débito ou crédito, ao final da corrida, com o próprio motorista do táxi. No modelo da UBER, o único método de pagamento é desconto direto do cartão de crédito. Segundo, o usuário não necessita informar previamente seu destino informado ao motorista do táxi, como no modelo UBER. 
Assim, é possível afirmar que, do ponto de vista da natureza econômica, entre o serviço prestado por meio da UBER e o serviço de táxi existem tanto uma identidade conceitual genérica quanto uma intersecção operacional parcial. A identidade conceitual reside no fato de que ambos são serviços de transporte individual de passageiro remunerado basicamente com base na distância percorrida pelo veículo. E a intersecção operacional decorre da circunstância de que, embora o serviço de táxi disponha de um espectro maior de modalidades de acesso, a modalidade de acesso ao táxi por meio de aplicativos para smartphones é essencialmente igual ao serviço prestado pela UBER, persistindo diferenças marginais (opções de pagamento e prévia definição do destino).

Por outro lado, para além da "intersecção operacional parcial" entre táxi e UBER, apontada no parágrafo anterior, é evidente que a "identidade conceitual genérica" acima referida provoca um regime de competição entre o serviço prestado por táxis e o prestado pela empresa. Ambos operam no mercado de transporte individual remunerado de passageiros. É falso afirmar que a competição entre os dois formatos se circunscreve ao espaço de intersecção operacional parcial, isto é, entre os usuários de aplicativos para smartphones e tablets. Posto ser óbvio que entre os usuários desses aparelhos a concorrência seja direta e imediata, também é evidente que os usuários de táxi pelas modalidades I, II e III acima descritas podem ser atraídos tanto por usuários da UBER quanto dos usuários de aplicativos de táxi.

O problema da concorrência entre os sistemas é bastante complexo e necessita investigação especializada e prolongada. É possível que o modelo UBER crie uma demanda de serviço que não era produzida ou alimentada pelo serviço de táxi. É perfeitamente plausível conjecturar que pessoas que não fazem uso de táxi podem se sentir atraídas pela qualidade dos serviços prestados pela UBER. Nesse caso, o ingresso da UBER no setor econômico de transporte individual de passageiros remunerado não afetaria o serviço de táxi. Ainda assim, também parece possível presumir que muitos usuários de táxi podem se sentir atraídos exatamente pela qualidade dos serviços prestados pelo novo modelo e, portanto, podem migrar completamente para o sistema da empresa ou usar alternativamente um ou outro modelo. Aceitas essas premissas, é evidente que os serviços de transporte individual de passageiros prestados por meio do aplicativo UBER competem com o serviço de táxi. ${ }^{3}$

\footnotetext{
${ }^{3}$ Nesse sentido, o estudo elaborado em dezembro de 2015 por Luiz Alberto Esteves, Economista-Chefe do CADE, que afirma inexistirem evidências de impacto negativo dos serviços prestados pela UBER ao modal táxi, não parece oferecer dados conclusivos. Isso porque o estudo parte de um recorte muito limitado do
} 
Muitos outros fatores econômicos merecem uma investigação mais cuidadosa e metódica. O serviço de transporte individual remunerado de passageiros foi historicamente prestado por táxis em praticamente todo o mundo. Mais: o serviço de táxi sempre tendeu a gozar de um regime monopolista na prestação desse tipo de serviço. Trata-se, portanto, de uma instituição tradicional e solidamente assentada, com forte esprit de corps. Além disso, há certo consenso de que o setor é extensamente dominado por cartéis ou grupos bem organizados, capazes de exercer constante e influente pressão sobre as instâncias governamentais. Essas circunstâncias justificariam, ao menos em parte, a resistência que os taxistas têm manifestado publicamente, muitas vezes de forma violenta, contra a entrada dos serviços da empresa no mercado.

Por outro lado, os serviços oferecidos pela UBER possuem claramente uma natureza denominada de tecnologia disruptiva, termo que procura significar a capacidade de determinadas inovações tecnológicas de revolucionar uma determinada área da economia por apresentar uma melhor performance vis-à-vis os agentes econômicos tradicionais. Toda inovação disruptiva provoca reação de resistência nos setores atingidos. Os computadores aposentaram as maquinas de escrever. Os sites de procura na internet eliminaram as enciclopédias. Os serviços de streaming de música e filmes podem acabar com a indústria de CDs e DVDs e afetar drasticamente o tradicionalíssimo mercado das salas de cinema. Sistemas de intermediação de locação de imóveis como o Airbnb ameaçam tanto o setor hoteleiro quanto o de corretagem de imóveis. Sempre houve e há resistência a inovações disruptivas, entretanto a assimilação de novas tecnologias dificilmente pode ser contida, justamente porque recebe a adesão voluntária do público consumidor, que tende a valorizar as vantagens oferecidas pela inovação sem se preocupar com os efeitos negativos que a migração causa aos setores tradicionais.

Por isso, é perfeitamente natural a rápida adesão que os serviços da UBER têm recebido nas cidades onde se instalam. Os consumidores comparam os serviços de táxi com os serviços prestados por meio do novo modelo e relatam que os últimos possuem nítidas vantagens em relação aos primeiros, como a modernidade, a inovação tecnológica, a limpeza e o conforto dos automóveis, a educação dos motoristas e a pontualidade, gentileza na prestação do serviço. Os consumidores que comparam serviços de táxi e o serviço prestado pelos motoristas da UBER reclamam justamente da qualidade, da falta de limpeza e de conforto dos táxis, da falta de educação e do descaso de seus motoristas e da dificuldade de acessar os táxis. Chama a atenção, a

significado de impacto de uma atividade econômica sobre outra. Os fatores referidos no texto, por exemplo, não foram objeto de análise no estudo (estudo disponível no site do órgão). 
propósito, que esse conjunto de elogios ao sistema UBER e de críticas aos táxis é internacional, não sendo exclusivo das cidades brasileiras que já contam com a atuação da empresa. ${ }^{4}$

Feita essa breve introdução explicativa do modelo, podemos agora ingressar no debate acerca do difícil problema jurídico a respeito da compatibilidade do modelo utilizado pela UBER com o sistema jurídico brasileiro.

\section{A NATUREZA JURÍDICA DO SERVIÇO DE TRANSPORTE INDIVIDUAL REMUNERADO DE PASSAGEIROS}

Como vimos no item anterior, o serviço de transporte individual remunerado de passageiros, por meio de veículo automotor, há muito é exercido de forma praticamente exclusiva por meio de táxis. Desde o surgimento do serviço de táxi, que aparece e se prolifera logo no início do século XX, a atividade foi fortemente regulada pelo Poder Público, especialmente em relação a quatro elementos: o modo de ingresso dos veículos e dos motoristas no exercício da atividade, o número de veículos que pertencem ao sistema, a fixação e regulação de tarifas e a distribuição dos veículos no espaço urbano.

Isso explica porque, no Brasil, há uma tendência de considerar o táxi uma espécie de serviço público, e não uma atividade econômica privada passível de regulação normativa pelo Poder Público. Frequentemente se entende que o serviço de táxi atende a um interesse público dotado de características que exigem a incidência de um regime jurídico de direito público, e não a sujeição à lógica típica da economia de mercado. Mesmo aqueles que não chegam ao ponto de considerar o serviço de táxi necessariamente um espécie de serviço público tendem a considerá-lo uma atividade econômica de alto de interesse público, que exige uma extensa regulação por parte do Estado.

A questão da natureza jurídica do serviço de transporte individual remunerado de passageiros é decisiva para a definição do problema da legalidade dos serviços prestados por meio da UBER. Como veremos, as consequências jurídicas são substancialmente diferentes dependendo do enquadramento conceitual que imputarmos aos serviços de transporte em questão. Por tal razão, é importante esclarecermos os pontos centrais da controvérsia jurídica.

\footnotetext{
4 Para uma comparação interessante entre os dois sistemas, ver especialmente Gustavo Binenbojm, Transformações do Poder de Polícia: Aspectos Político-Jurídicos, Econômicos e Institucionais, tese apresentada no concurso público para Professor Titular de Direito Administrativo na UERJ, 2015, p. 222-234.
} 
A dogmática do direito administrativo ocidental há muito tempo controverte acerca da natureza jurídica dos serviços públicos. Existem pelo menos três espécies de abordagens teóricas a respeito do tema.

As teorias essencialistas sustentam que determinadas atividades ou serviços são dotados de certas características que os tornam necessariamente públicos. ${ }^{5}$ Ser uma atividade ou um serviço público necessariamente significa ser um serviço prestado pelo Estado e submetido a um regime jurídico de direito público. Como se sabe, o Estado não é um ente natural. É uma criação intelectual relativamente tardia na história humana. ${ }^{6}$ Em certo sentido, é uma ficção jurídica. Entretanto, o conceito teórico de Estado, ainda que seja o produto de um desenvolvimento contingente da história cultural humana, pode ser formulado a partir de critérios gerais e estáveis para a identificação da ocorrência empírica do conceito na realidade. Assim, o caso central do conceito de Estado, no sentido moderno, pode ser definido como (a) a organização política de (b) uma comunidade humana dotada de (c) um governo soberano que exerce seu poder jurídico e político em (d) um espaço geográfico ou territorial delimitado (e) sobre o conjunto de indivíduos que habita esse território.

Partindo desse conceito teórico criterial de Estado, é possível deduzir que existem algumas atividades que são necessariamente atividades estatais, e, nesse sentido, atividades ou serviços públicos, submetidos a um regime de direito público. Atividades como a resolução de conflitos jurídicos com força coercitiva, a segurança pública necessária para garantir a obediência às normas jurídicas, a garantia da segurança dos membros da comunidade diante de violência externa e interna, a arrecadação de tributos, a gestão de aspectos básicos da economia, como emissão de moeda, são todas atividades que parecem ser necessariamente vinculadas ao Estado moderno. Todas elas já foram exercidas por pessoas privadas em momentos e lugares distintos na história da humanidade (há houve exércitos privados, justiça privada, emissão livre de moeda, etc.); ${ }^{7}$ porém, em um Estado moderno, dotado das características conceituais acima enunciadas, elas se tornaram atividades tipicamente estatais. Teríamos dificuldade de reconhecer como um Estado uma

\footnotetext{
${ }^{5}$ Um típico conceito essencialista é o proposto por Marçal Justen Filho; "Certa atividade é qualificada como serviço público em virtude de dirigir-se à satisfação direta e imediata de direitos fundamentais. Como consequência, essa atividade é submetida ao regime de direito público e, na maior parte dos casos, sua titularidade é atribuída ao Estado" (Curso de Direito Administrativo. São Paulo: Editora Saraiva, 2005, p. 482). ${ }^{6}$ Ver, a propósito, Francis Fukuyama. The Origins of Political Order: From Prehuman Times to French Revolution. New York: Farrar, Straus and Giroux, 2012.

${ }^{7}$ Nesse sentido, Diógenes Gasparini. Direito Administrativo. 13a edição. São Paulo: Editora Saraiva, p. 293.
} 
organização política no qual a jurisdição, a segurança pública interna e externa e a gestão tributária fossem exercidas por pessoas privadas.

Esse conceito essencialista pode nos auxiliar a identificar como serviços públicos muitas atividades hoje exercidas pelo Estado, como os serviços judiciários e de segurança pública, porém não explica a existência de serviços que são considerados públicos e que, no entanto, não podem ser considerados como decorrendo necessariamente do próprio conceito jurídico-político do Estado moderno. Atividades como fornecimento de água, energia elétrica, saneamento básico não são necessariamente vinculados ao conceito moderno de Estado. Um Estado continua sendo um Estado se deixa o exercício dessas atividades aos agentes econômicos privados. Podemos questionar a qualidade de vida ou a justiça distributiva nessas comunidades políticas, mas elas não deixam de ser um Estado no sentido moderno. No entanto, essa consequência apenas mostra a insuficiência do conceito essencialista de serviço público, e não que essas atividades não podem ser consideradas como serviço público.

As teorias de conveniência prestacional elegem como núcleo conceitual o fato de que muitas atividades se tornaram tão relevantes para o bem-estar dos indivíduos que compõem a comunidade e para a própria comunidade como um todo que é conveniente atribuir a sua prestação ao Poder Público. Isso significa que não é necessário que o serviço seja prestado pelo Estado, porém convém ao interesse geral da sociedade a sua atribuição a órgãos públicos. 0 serviço não é essencialmente público, como a jurisdição e a segurança pública, mas é melhor, mais útil, mais justo, mais eficaz para o interesse público, atribuir-Ihe ao Estado. ${ }^{8}$

Assim, os serviços de prestação de energia elétrica, de água potável, de saneamento básico (como esgotamento sanitário, coleta e destinação final de resíduos sólidos), construção e manutenção de infraestrutura de transportes (rodovias, portos, aeroportos), saúde e educação não são ligados necessariamente ao conceito de Estado. Todos podem, foram e ainda são prestados

\footnotetext{
${ }^{8}$ Essa parece ser a concepção teórica de Diógenes Gasparini: “conceituamos serviço público como sendo toda atividade de fornecimento de utilidade ou comodidade fruível preponderantemente pelos administrados, prestada pela Administração Pública ou por quem Ihe faça as vezes, sob um regime de Direito Público, instituído em favor de interesses definidos como próprios pelo ordenamento jurídico" (ob. cit., p. 294). Celso Antônio Bandeira de Mello também parece filiar-se, em parte, a essa concepção: "Serviço público é toda atividade de oferecimento de utilidade ou comodidade material destinada à coletividade em geral, fruível singularmente pelos administrados, que o Estado assume como pertinente a seus deveres e presta por si mesmo ou por quem Ihe faça as vezes, sob um regime de Direito Público - portanto, consagrador de prerrogativas de supremacia e de restrições especiais, instituído em favor dos interesses definidos como públicos no sistema normativo" (Curso de Direito Administrativo. 16a edição. São Paulo: Editora Malheiros, p. 612). Contudo, na parte final do conceito o autor associa à sua concepção de conveniência uma posição decisionista, cuja definição faremos a seguir.
} 
pela iniciativa privada. No entanto, determinados critérios (como justiça distributiva, eficiência da gestão, economicidade, adequação de qualidade e quantidade) podem justificar a conclusão de que é mais conveniente ao interesse público que eles sejam prestados por agentes econômicos privados.

Por fim, as teorias da decisão estatal sustentam que a definição sobre a natureza de serviço público de uma determinada atividade pertence ao poder público, especialmente por meio de suas instâncias legislativas, seja o poder constituinte, seja o poder legislativo ordinário, que pode definir discricionariamente e sem qualquer compromisso com critérios essencialistas ou de conveniência pública quais atividades serão exercidas como serviço público, submetendo-se ao regime jurídico de direito público. ${ }^{9}$ Essas concepções teóricas afirmam que uma atividade é serviço público pelo simples fato de constar em uma fonte social do direito, como a constituição ou uma lei, como serviço público, ainda que ela não seja necessariamente vinculada ao conceito de Estado ou que ela não atenda a nenhum interesse público de relevância geral. Assim, as teorias da decisão estatal implicam uma teoria da positividade do serviço público. ${ }^{10}$

\footnotetext{
${ }^{9}$ Poderíamos citar Hely Lopes Meirelles como um caso paradigmático de autor que sustenta uma teoria da decisão estatal a partir da seguinte passagem da sua obra clássica: "Também não é a atividade em si que tipifica o serviço público, visto que algumas tanto podem ser exercidas pelo Estado quanto pelos cidadãos, como objeto da iniciativa privada, independentemente da delegação estatal, a exemplo do ensino, que, ao lado do oficial, existe o particular, sendo aquele um serviço público e este não. O que prevalece é a vontade soberana do Estado, qualificando o serviço como público ou de utilidade pública, para sua prestação direta ou indireta, pois serviços há que, por sua natureza, são privativos do Poder Público e só por seus órgãos devem ser executados, e outros são comuns ao Estado e aos particulares, podendo ser realizados por aquele e estes" [grifei] (Direito Administrativo Brasileiro. 33a edição. São Paulo: Editora Malheiros, p. 331); contudo, percebe-se na parte final do parágrafo a falta de rigor analítico que caracteriza a conceituação de serviço público, já que, embora apresente uma concepção baseada na decisão soberana do Estado, o autor admite a existência de serviços que, "por sua natureza, são privativos do Poder Público", o que corresponde a uma concepção essencialista de serviço público.

${ }^{10}$ Nesse sentido, Rafael Maffini: "Assim, numa acepção formal, uma determinada atividade somente poderá ser definida como serviço público caso seja assim qualificada pela própria Constituição Federal ou, em alguns casos, pela legislação infraconstitucional. Ou seja, não é serviço público aquilo que se deseja, mas o que a ordem jurídica assim qualifica" (Direito Administrativo. 3a edição. São Paulo: Editora RT, p. 182). Maria Sylvia Zanella Di Pietro também adere à concepção decisionista e positivista de serviço público: "é o Estado, por meio da lei, que escolhe quais as atividades que, em determinado momento, são consideradas serviços públicos; no direito brasileiro, a própria Constituição faz essa indicação nos artigos 21, incisos, X, XI, XII, XV e XXIII, e 25, \& 20, alterados, respectivamente, pelas Emendas Constitucionais n. 8 e 5, de 1995; isto exclui a possibilidade de distinguir, mediante critérios objetivos, o serviço público da atividade privada; esta permanecerá como tal enquanto o Estado não a assumir como própria" [grifei] (Direito Administrativo. 26a edição. São Paulo: Editora Atlas, p. 105). Agustín Gordillo também oferece um claro exemplo de concepção decisionista "se segue de todo o exposto que o elemento que determina a necessidade de aplicar um regime jurídico especial é o monopólio legal conferido pelo Estado. Em outras palavras, a decisão que se adota em matéria de política econômica é a que leva a um determinado regime jurídico ou outro" [grifei] (Tratado de Derecho Administrativo. Tomo II.. Belo Horizonte: Editora Del Rey, VI-33).
} 
Naturalmente as duas primeiras concepções teóricas são mais problemáticas e, por isso mesmo, mais contestadas. Definir o que é essencialmente serviço público em razão das características conceituais do Estado ou que serviços é conveniente ao interesse público atribuir ao Estado depende de concepções ideológicas e ético-políticas subjetivas que são sempre objeto de intensa divergência e controvérsia. A teoria da decisão estatal acerca do que é serviço público é, neste sentido, mais objetiva, e, por consequência, mais infensa a controvérsias. Não admira, portanto, que ela tenda a ser preferida pelos autores que tratam do tema na dogmática jurídica. Teorias essencialistas e de conveniência prestacional servem apenas como inspiração à decisão do autoridade legislativa e como padrão de crítica política ou teórica às escolhas do legislador constitucional ou ordinário quando elege tornar determinada atividade serviço público.

No direito brasileiro, prevalece a tendência de considerar serviço público apenas as atividades que estão previstas como serviço público nas fontes formais de direito, como a Constituição Federal e a legislação. A Constituição Federal de 1988 prevê uma série de serviços classificados como públicos. No artigo 21, que contempla as competências materiais da União, estão definidos como públicos os serviços de telecomunicações (XI), radiodifusão sonora e de sons e imagens (XII, a), energia elétrica (XII, b), navegação aérea, aeroespacial e infraestrutura aeroportuária (XII, c), transporte ferroviário e aquaviário (XII, d), transporte rodoviário interestadual e internacional (XII, e), portos marítimos, fluviais e lacustres (XII, f). O artigo 198 prevê o serviço público de saúde, o artigo 208 prevê o serviço público de educação básica gratuita. $\mathrm{O}$ artigo 30, V, prescreve competir aos Municípios organizar e manter os serviços públicos de interesse local, incluído o de transporte coletivo, que tem caráter essencial.

A interpretação que prevalece no direito público brasileiro conclui que a lista de serviços públicos inscritas na Constituição Federal não é fechada ou exclusiva. Ou seja, os poderes legislativos dos entes federados detêm competência normativa para instituir novas hipóteses de serviço público. O referido artigo 30, V, da Constituição Federal provê, nesse ponto, um argumento decisivo a favor dessa exegese, já que contem uma cláusula geral atributiva de competência legislativa, ao dizer que compete aos Municípios organizar e manter os serviços públicos de interesse local, sem especificar quais seriam eles. Quando o texto da norma afirma que o transporte coletivo é um serviço público municipal, fica evidente que se trata de uma hipótese meramente exemplificativa de serviço público municipal.

A principal consequência da adscrição de uma determinada atividade à categoria de serviço público é o seu regime jurídico. Os serviços públicos submetem-se sempre a um regime 
jurídico de direito público. O eixo normativo do direito dos serviços públicos no sistema jurídico nacional é o artigo 175 da Constituição Federal, segundo o qual "Incumbe ao Poder Público, na forma da lei, diretamente ou sob regime de concessão ou permissão, sempre através de licitação, a prestação de serviços públicos". Portanto, serviços públicos ou são prestados diretamente pela Administração Pública ou são prestados por agentes privados mediante concessão ou permissão do Poder Público titular do serviço. Os agentes econômicos privados não são livres para iniciarem uma atividade definida como serviço público. A previsão legal de que um serviço é público exclui a incidência do direito fundamental à liberdade econômica. Além disso, o modo de prestação dos serviços públicos é objeto de ampla e tendencialmente completa regulamentação legal.

Para além dos serviços públicos, também existem os serviços denominados de utilidade pública. O conceito de serviço de utilidade pública tem uma história acidentada na história do direito administrativo brasileiro e jamais gozou de um consenso doutrinário e jurisprudencial. A melhor explicação para a inserção desse conceito no direito administrativo brasileiro afirma que ele deriva do conceito de public utilities, típico do direito norte-americano, o qual se caracteriza por se referir a atividades prestadas por agentes econômicos privados que, por sua relevância ao interesse público, podem e devem ser objeto de uma regulação normativa mais rigorosa e extensa por parte do Estado. ${ }^{11} \mathrm{~A}$ natureza dessa regulação não é bem esclarecida. Pode consistir em mecanismos de controle da instalação da atividade, como a exigência de autorização administrativa prévia, em regras mais ou menos restritivas e extensas a respeito do modo de prestação e uma fiscalização mais rigorosa do serviço.

Um exemplo de serviço de utilidade pública é a educação privada, que é expressamente permitida pelo artigo 209, caput, da Constituição Federal. Quando prestada por entidades privadas, a educação é uma atividade econômica, que pode ou não ser exercida com fins lucrativos. Contudo, em virtude da sua notória relevância para o interesse público, já que a educação é um direito fundamental (art. 6ํ, CF), ela se submete a uma mais rigorosa e extensa regulação legal. Assim, o inciso I do próprio artigo 209 da CF condiciona o exercício da atividade de educação privada à autorização do Poder Público. O artigo 210 prevê que o Estado fixará conteúdos mínimos para o ensino fundamental. A Lei Nacional de Diretrizes e Bases para a Educação (Lei n. 9.394/96) incide inclusive sobre as instituições privadas de ensino. Essas

\footnotetext{
${ }^{11}$ Ver, para um estudo detalhado da história do conceito no direito brasileiro e sua origem no direito norteamericano, ver José Guilherme Giacomuzzi, "O serviço de táxi é serviço público? Em torno de conceitos e da esquizofrenia no direito administrativo brasileiro", 2016, artigo inédito, gentilmente cedido pelo autor.
} 
circunstâncias permitem concluir que o serviço de educação prestado por entidades privadas é uma atividade econômica que se caracteriza por ser um serviço de utilidade pública.

Mais adiante retornaremos ao exame do conceito de serviço de utilidade pública. O esboço acima apresentado é suficiente para prosseguirmos na questão da natureza jurídica do serviço de transporte individual de passageiros. Como vimos acima, historicamente o transporte individual remunerado de passageiros foi prestado exclusivamente por meio de táxis, razão pela qual a análise da definição da natureza jurídica dessa atividade passa por compreender a história da regulação do serviço de táxi no direito brasileiro.

Tradicionalmente, o serviço de táxi foi considerado ou uma espécie de serviço público ou um serviço de utilidade pública, sendo, portanto, objeto de extensa regulamentação legal. ${ }^{12}$ Além disso, sempre foi considerado serviço de interesse local, razão pela qual se entendeu que a organização e a regulamentação são de competência legislativa e executiva dos Municípios. Essa interpretação teve o efeito de produzir uma grande variedade de soluções locais. Muitos Municípios definiram e definem o serviço de táxi como serviço público e outros sequer se preocupam em render-se a definições precisas, ainda que regulamentem o exercício da atividade por meio de normas que se assemelham ora a um regime de serviço público ora a um regime de serviço de utilidade pública.

A emergência da Lei Federal n. 12.587, de 03 de janeiro de 2012, que instituiu o Estatuto da Política Nacional de Mobilidade Urbana, alterou completamente esse panorama tradicional de pluralidade de soluções normativas municipais. Pela primeira vez o direito positivo brasileiro passou a contar com normas jurídicas de direito administrativo regulamentando, entre outros modais de transporte urbano, o serviço de transporte individual remunerado de passageiros. E os conceitos e regimes jurídicos previstos na nova legislação incidem integralmente na questão jurídica que estamos analisando, razão pela qual é indispensável conhecer e interpretar a lei para encontrar as respostas adequadas ao problema.

O artigo 3으, $\S \S 1$ e 2으, da Lei n. 12.587/2012 tem como escopo classificar as espécies de transportes urbanos admitidos no direito brasileiro. ${ }^{13}$ Já o artigo 4으 do estatuto ocupou-se de

\footnotetext{
12 Ver José Guilherme Giacomuzzi, "O serviço de táxi é serviço público? Em torno de conceitos e da esquizofrenia no direito administrativo brasileiro", cit., Gustavo Binenbojm, Transformações do Poder de Polícia: Aspectos Político-Jurídicos, Econômicos e Institucionais, cit..

${ }^{13}$ Art. $3^{\circ}$ O Sistema Nacional de Mobilidade Urbana é o conjunto organizado e coordenado dos modos de transporte, de serviços e de infraestruturas que garante os deslocamentos de pessoas e cargas no território do Município. § $1^{\circ}$ São modos de transporte urbano: I - motorizados; e II - não motorizados.
} 
conceituar as classes de transporte urbano elencadas no dispositivo legal supracitado. ${ }^{14} \mathrm{~A}$ interpretação desses dispositivos permite ao intérprete formular as seguintes definições classificatórias a respeito do transporte individual de passageiros como modo de transporte urbano motorizado:

1. Transporte público individual, que é o serviço remunerado de passageiros aberto ao público, prestado por veículos de aluguel, para a realização de viagens individualizadas (art. 4 으, XIII);

2. Transporte privado individual, que é meio de transporte de passageiros utilizado para viagens individualizadas por intermédio de veículos particulares (art. 4ํㅡ, X).

Essas são as únicas modalidades de transporte individual de passageiros reguladas na Lei de Mobilidade Urbana. Como se pode facilmente constatar, existem, entre as modalidades, diferenças substanciais e decisivas. Em primeiro lugar, o transporte público individual é uma espécie de serviço remunerado; o transporte privado individual é apenas um meio de transporte não remunerado. Em segundo lugar, o transporte público individual é prestado por veículos de aluguel; o transporte privado é realizado por veículos particulares. A única semelhança entre o

$\S 2^{\circ}$ Os serviços de transporte urbano são classificados: I - quanto ao objeto: a) de passageiros; b) de cargas; II - quanto à característica do serviço: a) coletivo; b) individual; III - quanto à natureza do serviço: a) público; b) privado.

${ }^{14}$ Art. $4^{\circ}$ Para os fins desta Lei, considera-se:

I - transporte urbano: conjunto dos modos e serviços de transporte público e privado utilizados para o deslocamento de pessoas e cargas nas cidades integrantes da Política Nacional de Mobilidade Urbana; II mobilidade urbana: condição em que se realizam os deslocamentos de pessoas e cargas no espaço urbano; III - acessibilidade: facilidade disponibilizada às pessoas que possibilite a todos autonomia nos deslocamentos desejados, respeitando-se a legislação em vigor; IV - modos de transporte motorizado: modalidades que se utilizam de veículos automotores; $\vee$ - modos de transporte não motorizado: modalidades que se utilizam do esforço humano ou tração animal; VI - transporte público coletivo: serviço público de transporte de passageiros acessível a toda a população mediante pagamento individualizado, com itinerários e preços fixados pelo poder público; VII - transporte privado coletivo: serviço de transporte de passageiros não aberto ao público para a realização de viagens com características operacionais exclusivas para cada linha e demanda; VIII - transporte público individual: serviço remunerado de transporte de passageiros aberto ao público, por intermédio de veículos de aluguel, para a realização de viagens individualizadas; IX - transporte urbano de cargas: serviço de transporte de bens, animais ou mercadorias; $X$ - transporte motorizado privado: meio motorizado de transporte de passageiros utilizado para a realização de viagens individualizadas por intermédio de veículos particulares; XI - transporte público coletivo intermunicipal de caráter urbano: serviço de transporte público coletivo entre Municípios que tenham contiguidade nos seus perímetros urbanos; XII transporte público coletivo interestadual de caráter urbano: serviço de transporte público coletivo entre Municípios de diferentes Estados que mantenham contiguidade nos seus perímetros urbanos; eXIII transporte público coletivo internacional de caráter urbano: serviço de transporte coletivo entre Municípios localizados em regiões de fronteira cujas cidades são definidas como cidades gêmeas. 
serviço de transporte público individual e o meio de transporte privado individual é exatamente a individualidade dos dois modos de transporte motorizado.

O uso de duas expressões completamente distintas é aqui muito significativo. O transporte público individual é um serviço prestado mediante remuneração, ou seja, é tipicamente um serviço no sentido econômico do termo. O transporte privado individual é definido como um meio de transporte realizado por veículos particulares. Não é um serviço, público ou privado. É o meio de transporte utilizado pelas pessoas privadas que usam automóveis, geralmente próprios, para se locomoverem nas áreas urbanas. Cuida-se de um meio de transporte que compõe o cenário da mobilidade em áreas urbanas.

Se analisarmos com cuidado o texto do artigo 4 veremos que o único outro transporte privado regulado na lei é o transporte coletivo privado, que, no inciso VII do dispositivo, é definido como "serviço de transporte de passageiros não aberto ao público para a realização de viagens com características operacionais exclusivas para cada linha e demanda" (grifei). Ou seja, o transporte coletivo privado é um serviço, como o transporte público individual; o transporte privado individual não é um serviço, é um meio. Portanto, não tem expressão econômica. Não é uma atividade econômica que um agente econômico fornece para um consumidor ou usuário.

A conclusão que se extrai desse raciocínio é que o inciso $X$ do artigo 4 o da Lei $n$. 12.587/2012 não pode ser invocado como fonte normativa do direito da UBER ou de seus motoristas credenciados de prestarem o serviço de transporte individual remunerado. Como vimos, $\mathrm{O}$ inciso $\mathrm{X}$ regula exclusivamente o meio de transporte individual em veículos motorizados usados pelas pessoas privadas nas áreas urbanas. Ele não regula nenhuma forma de serviço de transporte.

Resta, portanto, apenas o modo de transporte definido como transporte público individual, que, como já examinamos, é o "serviço remunerado de transporte de passageiros aberto ao público, por intermédio de veículos de aluguel, para a realização de viagens individualizadas". Vale a pena enfatizar: o único tipo de serviço de transporte individual é o transporte público individual, regulado no inciso VIII do artigo 4ㅇ․ Não existe serviço de transporte privado individual na sistemática da lei. Por conseguinte, o argumento utilizado pela UBER para sustentar que tem direito subjetivo a prestar o que chama de serviço de transporte privado individual não encontra fundamento normativo no inciso X do artigo 4음 da Lei Nacional de Mobilidade Urbana.

Isso significa que todo serviço de transporte individual é um serviço público? Isso não é dito nos enunciados normativos em exame. Transporte público não implica serviço público. o 
vocábulo público caracteriza aqui o transporte, não a natureza jurídica do serviço. De fato, o texto o inciso VIII sugere que o que configura a publicidade do transporte público individual é o fato de "ser aberto ao público", não o fato de se submeter ao regime jurídico típico de serviço público.

Assim, de acordo com a norma legal referida, um modo de transporte é transporte público individual sempre que apresentar as seguintes características: (i) seja prestado para a realização de viagens individualizadas; (ii) seja remunerado; (iii) seja aberto ao público; (iv) seja prestado por intermédio de veículos de aluguel. Definidas essas características abstratas, extraídas de uma compreensão textual do enunciado normativo, precisamos agora tentar empregá-las aos casos concretos relevantes para ver se e como eles se ajustam ao tipo normativo abstrato.

Em princípio, não há muita dificuldade com as características (i) e (ii). Com efeito, o uso ordinário das expressões "viagem individualizada" e "remuneração" parece suficiente para compreender o significado do texto legal. Todavia, as expressões "aberto ao público" e "por intermédio de veículos de aluguel" parecem mais complicadas.

A expressão "aberto ao público" terá que se submeter a uma definição estipulativa, já que não há, na linguagem jurídica do direito brasileiro, uma definição lexical do que seja "aberto ao público". ${ }^{15}$ Tudo indica que a melhor interpretação do termo é considerar aberto ao público o serviço que é oferecido publicamente a um grupo indeterminado de pessoas. Uma loja de departamentos, um site de compras pela internet e um espetáculo teatral podem ser considerados aberto ao público. Um serviço seria fechado ao público quando é oferecido a um grupo determinado de pessoas, escolhido pelo prestador de serviços. O serviço de advocacia privada não é aberto ao público. O advogado tem o poder de escolher os clientes e as causas que quer defender.

${ }^{15}$ Conforme Irving M. Copi e Carol Cohen, "aquele que introduz um novo símbolo tem completa liberdade para estipular o sentido a ser dado a ele; a definição que emerge da determinação deliberada de um significado é adequadamente chamada de estipulativa. O termo assim definido não necessita ser inteiramente novo; ele pode ser novo somente no contexto no qual a sua definição é empregada" (Introduction to Logic. 10ª edição. Editora Prentice Hall, 1998, p. 125). Já "onde o objetivo da definição é eliminar ambiguidade ou aumentar o vocabulário daquele que o está construindo, então o termo a ser definido não é novo, mas tem um uso estabelecido; a definição é lexical, ao invés de estipulativa" (ob. cit., op. 127). Riccardo Guastini leciona que "(i) As definições informativas descrevem em qual modo ou em quais modos a expressão definida é efetivamente usada por qualquer um, Típico exemplo, as definições lexicais (ou lexicográficas) contidas nos dicionários de uma língua, os quais descrevem em qual modo (ou mais frequentemente, em quais modos) uma palavra é comumente usada por aqueles que falam a língua em questão. (ii) As definições estipulativas, pelo contrário: (a) estabelecem como usar um termo ou um sintagma novo (estipulação pura), ou (b) propõem usar um termo ou um sintagma preexistente de um modo novo (outro tipo de estipulação pura), ou, ainda (c) propõem usar um termo ou um sintagma preexistente de um modo mais preciso em relação ao uso comum (redefinição) (Interpretare e Argumentare. Milão: Giuffré Editora, 2011, p. 25-26)

Revista de Direito da Cidade, vol. 08, no 2. ISSN 2317-7721 pp.775-812 
A expressão "por intermédio de veículos de aluguel" é mais complicada porque o vocábulo "aluguel" tem um significado bem preciso no direito brasileiro. Trata-se de um contrato típico, denominado de locação no Código Civil. De acordo com o artigo 565 do CC, "na locação de coisas, uma das partes se obriga a ceder à outra, por tempo determinado ou não, o uso e gozo de coisa não fungível, mediante certa retribuição". Perceba-se como o conceito legal de locação ou aluguel turva a compreensão do que o legislador quis dizer com "por intermédio de veículos de aluguel" na definição do conceito de transporte público individual. Isso porque o prestador de serviço de transporte não aluga o seu veículo ao passageiro. O veículo continua na posse direta do prestador de serviço durante a viagem. E não parece plausível exigir que o prestador do serviço de transporte público individual tenha que necessariamente possuir um "veículo de aluguel" para prestar o serviço. Porque ele não poderia prestar o serviço com o seu próprio veículo?

O enigma do significado dessa expressão sui generis é superado com o recurso ao Código de Trânsito, cujo artigo 96, III, d, lista o "veículo de aluguel" como uma das categorias de veículos, cujo artigo 135 define a categoria da seguinte forma:

Art. 135. Os veículos de aluguel, destinados ao transporte individual ou coletivo de passageiros de linhas regulares ou empregados em qualquer serviço remunerado, para registro, licenciamento e respectivo emplacamento de característica comercial, deverão estar devidamente autorizados pelo poder público concedente.

Portanto, veículos individuais de aluguel são veículos destinados ao transporte individual de passageiros empregados em qualquer serviço remunerado. Claramente não é um significado técnico, que se ajuste ao conceito legal de contrato de locação. Trata-se, tudo indica, da consolidação no texto do Código de Trânsito de um uso coloquial antigo da expressão "veiculo de aluguel". Sendo esse o significado de veículo de aluguel, pode-se afirmar que o inciso VIII do artigo 4o da Lei n. 12.587/2012 contém uma redundância, já que conceitua o transporte público individual como serviço remunerado prestado por intermédio de veículo de aluguel, o que já estava pressuposto na referência à remuneração do serviço.

Feitas essas considerações a respeito da interpretação dos conceitos legais de transporte público individual e de transporte privado individual, previstos respectivamente nos incisos VIII e X do artigo 40 da Lei n. 12.587/2012, podemos agora tentar enquadrar os serviços prestados pela UBER em uma dessas modalidades.

Já afastamos acima a subsunção dos serviços da UBER no conceito de transporte privado individual, que, como vimos, é um meio de transporte utilizado por pessoas privadas na área urbana, não é um serviço, não tem expressão econômica. O serviço prestado por meio do 
aplicativo é um serviço de transporte de passageiros. Trata-se de uma atividade econômica, em que um agente econômico realiza uma ação que satisfaz uma necessidade de outra pessoa e recebe dessa uma remuneração pela ação executada. Essa atividade consiste em transportar uma pessoa de um local a outro dentro de um veículo automotor, ou seja, cuida-se de um típico de serviço de transporte.

Não há dúvida de que se trata de serviço remunerado. O usuário do serviço paga pelo transporte entre dois pontos, ainda que o faça na forma muito moderna do débito direto no seu cartão de crédito já previamente cadastrado em um aplicativo de smartphone. Creio que ninguém ousaria dizer que o serviço é gratuito ou que o pagamento efetuado pelo usuário não é "remuneração". Por conseguinte, para os efeitos do artigo 135 do Código de Trânsito, o veículo que presta serviço por meio da UBER é um "veículo de aluguel".

Resta saber se o serviço prestado por meio da UBER é aberto ao público. Como vimos, não existe uma definição legal de "serviço aberto ao público". Também não parece haver uma definição lexical, ou seja, uma definição consolidada pelo uso ordinário da expressão na sociedade brasileira. Temos que nos valer de um conjunto de dados conhecidos e compreendidos para propor uma definição estipulativa, isto é, uma definição que propõe o melhor significado possível para o uso da expressão. Acima propusemos que o melhor conceito estipulativo de serviço aberto ao público é o serviço que é oferecido publicamente a um grupo indeterminado e indeterminável de pessoas.

Pois bem, está claro que, partindo do conceito proposto, o sistema UBER é aberto ao público. Conquanto apenas as pessoas cadastradas no aplicativo possam acessar o serviço, qualquer pessoa pode efetuar o cadastro. O acesso ao serviço oferecido pela UBER não é diferente do acesso a serviços similares como EASY TAXI e 99TAXIS e a sites de compra de produtos pela internet, que também exigem prévio cadastramento dos potenciais clientes. Pode-se afirmar, pois, que os serviços oferecidos pela UBER também apresentam a característica de serem abertos ao público.

Assim, podemos concluir que os serviços oferecidos pela UBER apresentam todas as características que o artigo 4ํ, VIII, da Lei n. 12.587/2012 atribui ao conceito de transporte público individual, ou seja, trata-se de serviço (i) prestado para a realização de viagens individualizadas, (ii) remunerado; (iii) aberto ao público e (iv) prestado por intermédio de veículos de aluguel. Não se trata, assim, de serviço privado individual, previsto no inciso $X$ do artigo 4․ Como vimos, essa figura legal se refere ao meio de transporte empregado por pessoas particulares para transitarem 
em veículos na área urbana. A UBER presta um serviço de transporte público individual, submetendo-se à disciplina do inciso VIII do artigo 4으 acima referido.

Antes de prosseguirmos, devemos ter em mente uma conclusão que chegamos acima. $\mathrm{Na}$ estrutura conceitual instituída pela Lei da Política Nacional de Mobilidade Urbana a expressão serviço de transporte público individual não significa serviço público de transporte individual, vale dizer, a lei não impôs ao serviço de transporte público individual o regime jurídico de serviço público. Conforme examinamos, no direito administrativo brasileiro prevalece a teoria da decisão estatal na definição do que é serviço público. Assim, se a Lei n. 12.587/2012 houvesse estipulado que o serviço de transporte público individual é um serviço público, essa previsão legal seria válida, já que o legislador detém o poder discricionário de dizer qual atividade é serviço público, e, por conseguinte, o serviço de transporte público individual submeter-se-ia a todas as consequências jurídicas típicas do regime de serviço público. Já vimos, contudo, que não é essa a conclusão que se deve chegar da interpretação do artigo 4ㅇ da lei.

Essa interpretação é confirmada pelos dispositivos da Lei n. 12.587/2012 que tratam especificamente do serviço de transporte público individual. Originalmente, a lei considerava esse tipo de transporte como serviço público. Vejamos a redação original do enunciado:

Art. 12. Os serviços públicos de transporte individual de passageiros, prestados sob permissão, deverão ser organizados, disciplinados e fiscalizados pelo poder público municipal, com base nos requisitos mínimos de segurança, de conforto, de higiene, de qualidade dos serviços e de fixação prévia dos valores máximos das tarifas a serem cobradas.

Quando lemos esse dispositivo é natural concluirmos que o legislador prescreveu que todo serviço de transporte público individual de passageiros era um tipo de serviço público, prestado mediante permissão do poder público competente. Ou seja, não haveria espaço para um serviço de transporte público individual que não fosse serviço público. Sem embargo, é preciso lembrar que o legislador de 2012 quase certamente restringia o campo de abrangência do conceito de transporte público individual ao serviço de táxi, que, conforme registramos, era praticamente o único tipo de serviço dessa natureza existente nas cidades brasileiras. Sendo assim, é possível supor que a intenção do legislador foi a de tratar o serviço de táxi como serviço público, provavelmente visando a resolver a antiga controvérsia dogmática e judicial acerca da natureza jurídica e do regime jurídico do serviço de táxi. ${ }^{16}$

\footnotetext{
${ }^{16}$ Ver, por todos, José Guilherme Giacomuzzi, "O serviço de táxi é serviço público? Em torno de conceitos e da esquizofrenia no direito administrativo brasileiro", cit.
} 
Não se pode excluir, contudo, que a emergência de novas modalidades de transporte público individual de passageiros pudesse ser prestada sem se submeter ao regime de serviço público. Lembremos que, nos termos da lei, transporte público individual é a atividade econômica que se caracteriza por ser um serviço (i) prestado para a realização de viagens individualizadas, (ii) remunerado; (iii) aberto ao público e (iv) prestado por intermédio de veículos de aluguel. Com a emergência de um novo tipo de serviço, como o oferecido pela UBER, poderíamos estar diante de um caso de transporte público individual que não se caracteriza por ser um serviço público.

Claro, essa interpretação necessita do apoio argumentativo do princípio constitucional da liberdade econômica, previsto no artigo 170, parágrafo único, da Constituição Federal, segundo o qual "É assegurado a todos o livre exercício de qualquer atividade econômica, independentemente de autorização dos órgãos públicos, salvo nos casos previstos em lei". De fato, esse princípio constitucional é muito importante na compreensão do problema jurídico sub examine o que explica ter sido tão explorado em pareceres jurídicos elaborados por juristas contratados pela empresa, da lavra dos eminentes professores Daniel Sarmento, ${ }^{17}$ José Joaquim Gomes Canotilho ${ }^{18}$ e André Ramos Tavares. ${ }^{19}$

Ocorre que o serviço de transporte individual de passageiros é, sem dúvida, uma atividade econômica. Isso porque se trata de um serviço remunerado, por meio do qual um usuário ou consumidor do serviço é transportado por um veículo automotor dirigido por um motorista de um determinado local até o destino desejado, pagando pelo transporte um determinado valor calculado com base na distância percorrida no trajeto. Uma atividade econômica pode ser convertida em serviço público por decisão do Poder Legislativo, independentemente da natureza da atividade, por força da prevalência da teoria da decisão estatal, estudada antes. E pode ser, inclusive, objeto de monopólio estatal por força de decisão legislativa.

Todavia, para que haja um monopólio estatal de uma determinada atividade econômica, na forma de um serviço público, deve haver uma norma legal proibindo o exercício dessa atividade econômica por parte da iniciativa privada. Caso contrário, incide o princípio previsto no artigo 170, parágrafo único, da Constituição Federal, que contempla o direito fundamental à livre iniciativa

17 Parecer do Prof. Daniel Sarmento disponível em http://s.conjur.com.br/dl/paracer-legalidade-uber.pdf, acessado em 08/03/2016.

18 Parecer do Prof. Gomes Canotilho disponível em http://sao-paulo.estadao.com.br/blogs/bruno-ribeiro/wpcontent/uploads/sites/281/2015/12/parecer-canotilho-uber.pdf, acessado em 08/03/2016.

19 Parecer do Professor André Ramos Tavares disponível em http://static1.squarespace.com/static/565cd127e4b09e25856aOfcc/t/5665e22ed8af1088bcd489d3/144951 7614071/Doc+1.pdf, acessado em 08.03.2016. 
econômica. E não existe, nem na Lei n. 12.587/2012 nem em qualquer outra lei a criação de um monopólio estatal da atividade econômica de transporte individual de passageiros, na forma de um serviço público. Portanto, em princípio incide o direito fundamental à livre iniciativa econômica, a partir do qual é possível formular uma norma inexpressa segundo a qual pessoas físicas e jurídicas estão autorizadas a - ou têm o direito subjetivo de - realizar a atividade econômica consistente na prestação do serviço de transporte individual remunerado de passageiros. ${ }^{20}$

Um importante obstáculo a esta conclusão é o artigo 2o da Lei n. 12.468, de 26 de agosto de 2011, que regulamentou a profissão de taxista. Este dispositivo legal tem a seguinte redação:

Art. 2 o É atividade privativa dos profissionais taxistas a utilização de veículo automotor, próprio ou de terceiros, para o transporte público individual remunerado de passageiros, cuja capacidade será de, no máximo, 7 (sete) passageiros.

Como sua redação deixa claro, esse enunciado normativo não institui nenhum tipo de serviço público, muito menos um monopólio estatal da atividade econômica de transporte público individual. O dispositivo apenas atribui aos profissionais denominados de taxistas o monopólio do transporte público individual de passageiros. A profissão de taxista tem as suas características definidas no artigo 3 o da referida lei. ${ }^{21}$ :

Ocorre que essa restrição absoluta do exercício da atividade econômica de transporte público individual remunerado de passageiros aos taxistas é incompatível com o artigo 5o, inciso XIII, da Constituição Federal, segundo o qual "é livre o exercício de qualquer trabalho, ofício ou profissão, atendidas as qualificações profissionais que a lei estabelecer". Essa norma constitucional prevê o direito fundamental à liberdade profissional. De acordo com o texto do enunciado, cuidase de um direito fundamental submetido à reserva legal qualificada.

Segundo Ingo Wolfgang Sarlet, as reservas legais qualificadas a direitos fundamentais "têm como traço distintivo o fato de estabelecerem pressupostos e/ou objetivos a serem atendidos pelo

\footnotetext{
${ }^{20}$ Sobre o conceito de norma inexpressa, ver Riccardo Guastini, Interpretare e Argumentare, cit.

${ }^{21} \mathrm{Art.} 3^{\circ} \mathrm{A}$ atividade profissional de que trata o art. $1^{\circ}$ somente será exercida por profissional que atenda integralmente aos requisitos e às condições abaixo estabelecidos: I - habilitação para conduzir veículo automotor, em uma das categorias B, C, D ou E, assim definidas no art. 143 da Lei no 9.503, de 23 de setembro de 1997; II - curso de relações humanas, direção defensiva, primeiros socorros, mecânica e elétrica básica de veículos, promovido por entidade reconhecida pelo respectivo órgão autorizatário; III - veículo com as características exigidas pela autoridade de trânsito; IV - certificação específica para exercer a profissão, emitida pelo órgão competente da localidade da prestação do serviço; $\vee$ - inscrição como segurado do Instituto Nacional de Seguridade Social - INSS, ainda que exerça a profissão na condição de taxista autônomo, taxista auxiliar de condutor autônomo ou taxista locatário; e VI - Carteira de Trabalho e Previdência Social CTPS, para o profissional taxista empregado.
} 
legislador ordinário para limitar os direitos fundamentais". ${ }^{22}$ Dimitri Dimoulis e Leonardo Martins afirmam haver reserva legal qualificada "quando a Constituição indica pelo menos um dos seguintes elementos: o tipo, a finalidade ou o meio de intervenção autorizados, dos quais o legislador poderá se valer quando de sua concretização da limitação constitucional do direito fundamental consubstanciado na reserva legal qualificada". ${ }^{23}$

O Supremo Tribunal Federal já decidiu que as restrições legais ao exercício de qualquer trabalho, ofício ou profissão devem se ater apenas a exigir qualificação e respeitar os princípios da razoabilidade e da proporcionalidade. Ao julgar o Recurso Extraordinário n. 511.961, em 16.06.2009, que tratava da constitucionalidade da exigência de diploma de curso universitário de jornalismo para o exercício da profissão de jornalista, a Corte definiu os limites do poder legislativo de restringir o exercício de trabalhos, ofícios e profissões. No mesmo ano de 2009, ao julgar o Recurso Extraordinário n. 414.426 (em 17.11.2009), o Supremo Tribunal Federal reiterou a sua orientação de que, no sistema constitucional brasileiro, a regra é a liberdade de exercício de qualquer trabalho, ofício ou profissão, e essa liberdade só pode ser restringida pelo legislador quando houver potencial lesivo na atividade.

Com base na posição do Supremo Tribunal Federal, é possível afirmar que o poder legislativo não poderia ter limitado o exercício do trabalho envolvido na atividade econômica de transporte público individual remunerado de passageiros a taxistas. É aceitável limitar a taxistas que preencham os requisitos legais o exercício do transporte público individual na modalidade de táxi. Contudo, não é razoável conceder a uma determinada corporação o monopólio de uma determinada atividade econômica, especialmente se esta atividade não exige nenhuma qualificação científica ou técnica especial e tampouco provoque algum risco à saúde e ao bemestar da população. E tal monopólio profissional é ainda menos admissível se admitirmos que a legislação vigente permite outras modalidades de transporte público individual remunerado de passageiros, para além do táxi, liberando o exercício do trabalho associado a essa atividade econômica para pessoas que não sejam taxistas. Ou seja, a lei que concedeu aos taxistas o monopólio do exercício da atividade econômica de transporte individual remunerado de passageiros não passa pelo escrutínio do princípio da razoabilidade, que é condição de validade constitucional das normas legais.

\footnotetext{
22 In Ingo Wolfgang Sarlet, Daniel Mitidiero e Luiz Guilherme Marinoni. Curso de Direito Constitucional. 2oㅡ edição. São Paulo: Editora RT, p. 345.

${ }^{23}$ Dimitri Dimoulis e Leonardo Martins. Teoria Geral dos Direitos Fundamentais. 4a edição. São Paulo: Editora Atlas, p. 147.
} 
Sendo assim, o artigo 2o da Lei n. 12.468/2011 só é constitucional e, por conseguinte, só é válido se o sujeitarmos a uma interpretação conforme a constituição, pela qual ele seja compreendido da seguinte forma: É atividade privativa dos profissionais taxistas a utilização de veículo automotor, próprio ou de terceiros, para o transporte público individual remunerado de passageiros, na modalidade de táxi, não havendo vedação para que outras pessoas exerçam a atividade econômica de transporte individual remunerado de passageiros, atendidas as exigências que a lei estabelecer. Ou seja, a constitucionalidade da norma depende de a sujeitarmos a uma redução teleológica, a fim de limitarmos o seu âmbito de incidência. Assim interpretada, a norma não proíbe o exercício da atividade econômica de transporte público individual de passageiros, regulada no artigo 4ํㅡ, VIII, da Lei n. 12.587/2012, por pessoas que não sejam taxistas.

Passemos agora às razões finais desse estudo. Já analisamos a redação original do artigo 12 da Lei n. 12.587/2012 e concluímos que ela não vedava o exercício da atividade econômica de transporte público individual remunerado de passageiros. Interpretamos o enunciado contextualizando com a circunstância de que, à época da edição da lei, o serviço de táxi era praticamente o único modo de prestação do serviço de transporte público individual de passageiros conhecido, e que, por isso, a previsão normativa deveria ser compreendida como tornando a atividade de táxi como serviço público, sem estender a natureza de serviço público a outras modalidades de transporte público individual de passageiros prestado pela iniciativa privada enquanto exercício do direito fundamental à liberdade econômica.

Ocorre que o artigo 12 da lei foi alterado pela Lei n. 12.865, de 2013, passando a ter a seguinte redação:

Art. 12. Os serviços de utilidade pública de transporte individual de passageiros deverão ser organizados, disciplinados e fiscalizados pelo poder público municipal, com base nos requisitos mínimos de segurança, de conforto, de higiene, de qualidade dos serviços e de fixação prévia dos valores máximos das tarifas a serem cobradas. (Redação dada pela Lei no 12.865, de 2013)

Art. 12-A. O direito à exploração de serviços de táxi poderá ser outorgado a qualquer interessado que satisfaça os requisitos exigidos pelo poder público local. (Incluído pela Lei no 12.865, de 2013)

$\S 1^{\circ}$ É permitida a transferência da outorga a terceiros que atendam aos requisitos exigidos em legislação municipal. (Incluído pela Lei no 12.865 , de 2013)

$\S 2^{\circ} \mathrm{Em}$ caso de falecimento do outorgado, o direito à exploração do serviço será transferido a seus sucessores legítimos, nos termos dos arts. 1.829 e seguintes do Título II do Livro V da Parte Especial da Lei n 10.406, de 10 de janeiro de 2002 (Código Civil). (Incluído pela Lei no 12.865, de 2013) 
$\S 3^{\circ}$ As transferências de que tratam os $\S \S 1^{\circ}$ e $2^{\circ}$ dar-se-ão pelo prazo da outorga e são condicionadas à prévia anuência do poder público municipal e ao atendimento dos requisitos fixados para a outorga. (Incluído pela Lei oㅡ 12.865, de 2013)

Como se pode observar, a mudança do texto do enunciado normativo foi muito significativa em termos de consequências jurídicas. Agora, o transporte individual de passageiros passou a ser classificado como serviço de utilidade pública, e não mais como serviço público. ${ }^{24}$ Além disso, considerando que o caput do artigo 12 trata dos serviços de utilidade pública de transporte individual de passageiros, no plural, e que o artigo 12-A regula o direito à exploração do serviço de táxi, parece plausível concluir que o legislador criou um gênero, o serviço de utilidade pública de transporte individual de passageiros (art. 12), e regulou uma de suas espécies, o serviço de táxi (art. 12-A), deixando em aberto a possibilidade de serem criadas outras modalidades de transporte público individual de passageiros.

Com efeito, não seria sintaticamente coerente referir, no caput do dispositivo legal, a expressão genérica "serviço de utilidade pública de transporte individual de passageiros", e em um de seus desdobramentos a expressão específica "serviço de táxi" se elas fossem equivalentes. A explicação mais razoável, do ponto de vista sintático, é entender que o primeiro conceito é um gênero do qual o segundo é uma espécie. Aceita essa interpretação, serviço de utilidade pública de transporte individual de passageiros e serviço de táxi não são equivalentes e tampouco são sinônimos, mas, como vimos, guardam uma relação classificatória de gênero e espécie.

A mudança é absolutamente decisiva e, como dissemos, produz importantes efeitos jurídicos. Como vimos, serviços de utilidade pública não são serviços públicos. São atividades econômicas exercidas por agentes econômicos da iniciativa privada na forma de prestação de um serviço que, por possuírem determinadas características, são consideradas de utilidade pública, com a consequência de que podem ser reguladas e controladas de forma mais densa pelo Poder Público do que as atividades econômicas que não são de utilidade pública.

Se o artigo 12 da Lei da Política Nacional de Mobilidade Urbana instituiu o gênero serviço de utilidade pública de transporte individual remunerado de passageiros, configurando normativamente o conceito do artigo 4으, VIII, da lei, seguem-se quatro importantes consequências:

\footnotetext{
${ }^{24}$ Uma importante questão é saber se, após a vigência da nova redação do artigo 12 da lei, podem os Municípios manter ou criar leis que conferem a esse serviço a natureza de serviço público, como ocorre com a recente Lei n. 11.582/2014 do Município de Porto Alegre. A respeito dessa questão jurídica, ver José Guilherme Giacomuzzi, "O serviço de táxi é serviço público? Em torno de conceitos e da esquizofrenia no direito administrativo brasileiro", cit. A complexidade jurídica da questão e a sua irrelevância para as respostas que a manifestação procura oferecer nos impede de analisá-la.
} 
(a) o serviço de táxi é apenas uma espécie do gênero, não sendo a única modalidade de exercício da atividade econômica; (b) é possível a existência de outras modalidades de prestação do serviço de utilidade pública de transporte individual remunerado de passageiros, para além do serviço de táxi; (c) o serviço de transporte individual remunerado de passageiros prestado por meio do aplicativo da empresa UBER é uma modalidade admissível de serviço de utilidade pública de transporte individual de passageiros; (d) outros agentes econômicos poder ser autorizados a prestar o serviço referido.

Vamos reconstruir o argumento. O transporte individual remunerado de passageiros é uma atividade tipicamente econômica. Ela não se liga a nenhum tipo de atividade essencialmente estatal e tampouco é dotada de características e efeitos tão relevantes para o bem-estar da comunidade que seria conveniente, do ponto de vista do interesse público, atribuir a sua prestação ao Poder Público. Em princípio, trata-se de atividade reservada aos agentes econômicos da iniciativa privada. Por outro lado, também é evidente que a atividade é dotada de características que exigem a regulação estatal para a proteção dos usuários ou consumidores do serviço. Parece dispensar maiores digressões afirma que o bem-estar dos usuários exige que o Estado exerça, de alguma forma, o controle dos motoristas que prestam o serviço, a qualidade dos veículos nele utilizado, o valor das tarifas cobradas, a existência de garantias jurídicas para a segurança dos passageiros.

Por isso, o serviço em questão se credencia a ser classificado como atividade econômica exercida pela iniciativa privada prestada na forma de serviço de utilidade pública. Portanto, o Congresso Nacional, ao editar a Lei n. 12.865/2013, alterando a redação do artigo 12 da Lei n. 12.587/2012, parece ter adotado o conceito juridicamente adequado para o serviço, tornando coerente a regulação legal do serviço de transporte público individual de passageiros definida no artigo 4으, VIII, da Lei n. 12.587/2012.

Sendo assim, podemos concluir que os serviços prestados por meio da empresa UBER e qualquer outra atividade econômica equivalente podem ser oferecidos ao público como uma modalidade de transporte público individual de passageiros. Não apenas não existe qualquer vedação legal como se pode admitir que o artigo 12 da lei, na interpretação desenvolvida no texto, contém uma norma permissiva da prestação do serviço de transporte público individual para agentes econômicos que não operam no modal táxi. Por outro lado, em razão da mesma base normativa, essas atividades econômicas exercidas pela iniciativa econômica serão sempre serviços 
de utilidade pública, o que tem implicações jurídicas decisivas para o regime jurídico de regulação desses serviços.

Qual o significado normativo da classificação da atividade econômica exercida por meio da UBER como serviço de utilidade pública? Quais os efeitos jurídicos dessa classificação? As respostas a essas perguntas exigem uma rápida análise do conceito de serviço de utilidade pública. Anotamos acima que serviços de utilidade pública são "atividades prestadas por agentes econômicos privados que, por sua relevância ao interesse público, podem e devem ser objeto de uma regulação normativa mais rigorosa e extensa por parte do Estado". Posto que essa definição pode servir de ponto de partida para um raciocínio jurídico acerca da aplicação do conceito em questão, precisamos de uma análise mais densa para responder as questões propostas.

Dissemos que serviços de utilidade pública são serviços prestados a usuários particulares por agentes econômicos da iniciativa privada que se caracterizam essencialmente por afetarem de forma relevante um ou mais interesses públicos ou sociais. Essa afetação relevante do serviço prestado sobre um interesse público ou social exige a intervenção do Estado nas relações jurídicas estabelecidas entre prestador do serviço e a respectiva coletividade usuária. Essa intervenção se dá na forma de regulação do serviço privado de utilidade pública. Como a afetação ao interesse público é relevante, a regulação deve ser proporcionalmente mais densa do que a regulação legal a que qualquer atividade econômica está sujeita.

Mas como, afinal, deve ser a regulação estatal de um serviço de utilidade pública? O texto do artigo 12 da Lei n. 12.587/2012 fornece algumas diretrizes para responder a pergunta. Prescreve o texto da norma que "Os serviços públicos de transporte individual de passageiros, prestados sob permissão, deverão ser organizados, disciplinados e fiscalizados pelo poder público municipal, com base nos requisitos mínimos de segurança, de conforto, de higiene, de qualidade dos serviços e de fixação prévia dos valores máximos das tarifas a serem cobradas". Portanto, o Poder Público deve (i) organizar, (ii) disciplinar e (iii) fiscalizar o serviço privado de transporte público individual de passageiros para regular, pelo menos, a segurança, o conforto, a higiene, a qualidade e a fixação prévia dos valores máximos das tarifas a serem cobradas dos usuários.

Com base nessas premissas, podemos formular algumas hipóteses de regulação estatal do serviço de utilidade pública de transporte público individual de passageiros: (a) o Poder Público pode exigir habilitação profissional dos motoristas de veículos automotores que prestarão o serviço; (b) o Poder Público pode exigir curso de formação específica para condução de veículos na prestação do serviço de transporte público individual de passageiros e controlar a sua vida 
pregressa criminal; (c) o Poder Público pode instituir exigências em relação ao tipo de veículo a ser utilizado na prestação do serviço, especialmente em relação à data de fabricação e as condições de segurança, conforto e higiene do veículo; (d) o Poder Público pode exigir a contratação de seguro para cobertura de acidentes, além do seguro obrigatório; (e) o Poder Público pode fixar tarifas máximas a serem cobradas dos usuários e para fiscalizar a cobrança de tarifas abusivas por parte dos prestadores de serviço; (f) o Poder Público pode estabelecer regras e procedimentos para suspender o direito dos motoristas prestadores do serviço de atuarem no transporte público individual sempre que eles ou seus veículos estejam em desacordo com as diretrizes definidas nos itens anteriores.

Nada impede que o Poder Público transfira para a empresa UBER e qualquer outro agente econômico similar o controle de hipóteses de regulação como os enunciados nos itens $a, b, c$ e d do parágrafo anterior. Entretanto, neste caso é imperioso que o Poder Público exerça fiscalização sobre as atividades de controle interno da empresa responsável pela operação do serviço, já que o controle da satisfação dos requisitos subjetivos e objetivos contemplados naquelas hipóteses é exercício de poder de polícia, que não pode ser transferido para empresas privadas pelo Poder Público.

Por fim, a questão mais tormentosa a respeito da densidade da regulação estatal do serviço de transporte público individual de passageiros é a possibilidade ou necessidade de autorização do Poder Público para a empresa UBER e qualquer outro agente econômico similar iniciarem suas atividades. O ato administrativo de autorização para exercício de atividade econômica por parte da iniciativa privada pertence ao que chamamos de "regulação de entrada".

Em importante, detalhado e recente estudo sobre o exercício do poder de polícia no direito público contemporâneo, em que se examinou detalhadamente da regulação estatal da atividade econômica, Gustavo Binenbojm expõe um exame comparativo entre o serviço de táxi e o modelo empregado pela UBER que merece nossa atenção. Ao tratar do conceito de "regulação de entrada", o autor afirma que "a regulação pode impor barreiras à entrada de empresas em determinado mercado, desde que presentes razões idôneas, à luz de finalidades legítimas erigidas pela ordem político-jurídica. A idoneidade das razões será avaliada de acordo com os custos e os benefícios prováveis da imposição da barreira de entrada, diante das características empíricas do 
mercado regulado, notadamente os incentivos e a estrutura comportamental dos agentes econômicos". 25

A seguir, o autor sustenta existirem pelo menos quatro razões que legitimam o exercício do controle pelo Poder Público para o início da operação de determinadas atividades econômicas: (i) proteção do consumidor contra produtos e serviços de baixa qualidade, diante da ineficácia de mecanismos concorrenciais puros ou da regulação de qualidade ou de informação; (ii) gestão de monopólios naturais, viabilizando, se for o caso, estruturas econômico-financeiras de subsídio cruzado; (iii) a seleção econômica de participantes aptos a satisfazer finalidades legítimas pretendidas, como técnica de alocação de recursos intrinsecamente escassos; e (iv) garantia da capacidade patrimonial-financeira dos participantes do mercado regulado. ${ }^{26}$ Logo adiante, o autor tece as seguintes considerações a respeito da questão:

Caso interessante é o do serviço de táxi, sujeito tanto à regulação de entrada como de preço. O controle de entrada teria por objetivo zelar pela segurança, conforto e disponibilidade do serviço aos seus usuários, mediante prévia seleção dos operadores. Como se verá no item IV.2.3.6, no entanto, o surgimento de novos modelos de negócios no setor de transporte individual de passageiros (economia de compartilhamento), associado a novas plataformas tecnológicas, coloca hoje em xeque a própria juridicidade dessa regulação de entrada, tendo em vista a existência de outros meios mais eficientes de satisfação dos consumidores, por menores preços e com melhor qualidade. ${ }^{27}$

A seguir:

A fiscalização de entrada (dos serviços de táxi)é apresentada como medida voltada a reduzir o impacto de externalidades negativas (pelo controle do volume de tráfego urbano e dos níveis de poluição ambiental) e a garantir a segurança de usuário e terceiros (ao permitir a verificação da habilitação técnica e da idoneidade moral dos condutores, além das condições de funcionamento dos veículos). O tabelamento de preços de preços volta-se a mitigar as assimetrias de informação e os altos custos de transação que oneram o usuário do serviço. Já os indicadores de performance buscam otimizar a qualidade do serviço e a segurança no exercício da atividade, estipulando, por exemplo, tempo máximo de rodagem dos automóveis, testes periódicos do veículo, regularidade do taxímetro, identificações no automóvel, verificação rotineira de antecedentes criminais do motorista, exames médicos, limites de idade, dentre outros requisitos. ${ }^{28}$

O autor compara cuidadosamente a natureza econômica e jurídica do serviço de táxi ao serviço prestado por meio da UBER, assinala algumas diferenças importantes e expõe as diversas

25 Gustavo Binenbojm, Transformações do Poder de Polícia: Aspectos Político-Jurídicos, Econômicos e Institucionais, ob. cit., p. 203.

${ }^{26}$ Gustavo Binenbojm, ob. cit., p. 225.

27 Gustavo Binenbojm, ob. cit., p. 205.

28 Gustavo Binenbojm, ob. cit., p. 224. 
vantagens do modelo UBER em relação ao modal táxi. Ao tratar da questão específica da "regulação de entrada", o autor apresenta razões que parecem contraindicar a instituição de mecanismos formais para controlar ou limitar a entrada da empresa na atividade de transporte público individual. Embora não chegue a se posicionar de forma categórica contra a regulação de entrada, Gustavo Binenbojm demonstra ser crítico do sistema de barreiras, inclusive em relação ao modal táxi:

É aí que as atuais barreiras à entrada no setor apresentam inconsistências. De fato, para lidar com externalidades há mecanismos regulatórios mais inteligentes do que a proibição. Como apontam João Manoel Pinho de Mello e Vinicius Carrasco, "é possível compatibilizar o UBER com a quantidade ótima de carros na rua. A melhor forma de se corrigir uma 'externalidade' negativa, como a causada pelo aumento de congestionamento, é colocando um imposto que faça os motoristas se confrontarem com os custos sociais que eles causam ao decidirem sair de carro". No mesmo sentido é a conclusão do Departamento de Estudos Econômicos do CADE (DEE/CADE). Em recente análise do setor, o órgão concluiu que "não há elementos econômicos que justifiquem a proibição de novos prestadores de serviços de transporte individual. Para além disso, elementos econômicos sugerem que, sob uma ótica concorrencial e do consumidor, a atuação de novos agentes tende a ser positiva". 29

Sem embargo das razões apresentadas pelo Professor Binenbojm, os serviços prestados pelos motoristas que operam no modelo da empresa UBER parecem exigir um mecanismo de regulação de entrada por alguns fundamentos que explicitaremos adiante, e, inclusive, pelo menos pela razão elencada no item (i) da lista transcrita acima (isto é, proteção do consumidor). Como a UBER rejeita publicamente a necessidade de prévia autorização estatal para operar seus serviços e a sua posição foi respaldada por pareceres de eminentes juristas especializados em Direito Público, vamos analisar esse tema com mais cuidado.

Como tem ocorrido em todas as cidades onde inicia suas operações, a UBER implantou o seu modelo em algumas cidades brasileiras sem qualquer autorização prévia do Poder Público, manifestando-se publicamente pela desnecessidade da permissão estatal para o exercício de suas atividades. Alguns Municípios reagiram, vedando o funcionamento da UBER, como ocorreu em São Paulo e Rio de Janeiro. O Município de Belo Horizonte editou a Lei n. 10.900, de 08 de janeiro de 2016, que instituiu o procedimento de "credenciamento de pessoas jurídicas que operam ou administram aplicativos baseados em dispositivos de tecnologia móvel ou outros sistemas georreferenciados destinados à captação, disponibilização e intermediação de serviços de transporte individual remunerado de passageiros no Município".

${ }^{29}$ Gustavo Binenbojm, ob. cit., p. 232-233. 
Conforme a análise que fizemos acima, uma das consequências jurídicas da definição da atividade econômica de transporte individual remunerado de passageiros como serviço de utilidade pública é a regulação mais densa da atividade por parte do Poder Público. Todavia, dessa proposição não podemos deduzir diretamente que o Poder Público possa exigir prévia autorização ou qualquer outro ato administrativo de regulação de entrada. É preciso aprofundar a reflexão para chegarmos a uma definição acerca dessa questão decisiva. O direito positivo não ajuda o intérprete, na medida em que o texto do artigo 12 da Lei n. 12.587/2012 dispõe que 'Os serviços de utilidade pública de transporte individual de passageiros deverão ser organizados, disciplinados e fiscalizados pelo poder público municipal", não sendo possível atribuir necessariamente à expressão "organizar" o significado de regular a entrada ou autorizar.

Contudo, a melhor interpretação dos preceitos normativos, dos conceitos dogmáticos e do contexto fático envolvidos no exercício da atividade econômica de transporte individual remunerado de passageiros no meio urbano leva à conclusão de que não apenas o Poder Público está autorizado a instituir algum sistema de controle da entrada dos agentes econômicos no sistema de mobilidade urbana como tem o dever de fazê-lo.

Em primeiro lugar, porque a UBER é apenas uma empresa de prestação de serviços de transporte individual remunerado de passageiros. Outros agentes econômicos que usam o mesmo modelo de acesso por aplicativo para smartphones já existem no mercado internacional e outros poderão surgir. Além disso, não há nenhuma razão para que outros modelos alternativos não possam ser implantados no exercício do mesmo direito fundamental à liberdade econômica que serve de base normativa para o funcionamento da atividade da empresa em questão. Podemos pensar, por exemplo, em empresas que ofereçam o serviço de transporte individual remunerado por telefone fixo ou celular, ou por sites na internet. Por força do princípio moral-jurídico da universalização, uma solução para a UBER deve ser aplicável a todo e qualquer agente econômico que queira exercer o mesmo tipo de atividade econômica. Permitir que a UBER funcione sem qualquer autorização ou outro ato de controle de entrada criará o dever moral-jurídico de permitir que qualquer outro agente que preste o mesmo tipo de serviço a atuar sem qualquer autorização.

O direito constitucional brasileiro destaca-se por ter incorporado, entre os princípios fundamentais que regulam a Administração Pública, o princípio da moralidade administrativa, previsto no artigo 37, caput, da Constituição Federal. Este princípio impõe ao Poder Público o dever jurídico de respeitar imperativos morais em todas as suas ações. O princípio da universalização é um dos mais importantes princípios da moralidade. Sua definição mais famosa e influente consta 
da primeira fórmula do imperativo categórico de Immanuel Kant, segundo a qual uma ação humana só é moralmente correta quando a sua máxima (isto é, o princípio subjetivo que a determina) pode ser convertida em uma lei universal das ações humanas. ${ }^{30}$ Esse imperativo se aplica integralmente à atuação do Poder Público. Se a UBER puder atuar sem prévio controle ou qualquer outro mecanismo de controle de entrada, qualquer outro agente que pretenda atuar no setor de transporte individual remunerado de passageiros também poderá fazê-lo nas mesmas condições.

Em segundo lugar, porque o exercício da atividade econômica de transporte individual remurado de passageiros tem impactos significativos na mobilidade urbana. Conforme está explícito na Política Nacional de Mobilidade Urbana instituída pela Lei n. 12.587/2012, o sistema de mobilidade urbana é um complexo de modos, serviços e infraestruturas diretamente vinculados à realização ótima do princípio constitucional do desenvolvimento sustentável, previsto no artigo 182, caput, da Constituição Federal ${ }^{31}$ e no 2oo I, do Estatuto da Cidade (Lei n. 10.257/2001). ${ }^{32}$

Conquanto muitos efeitos produzidos pela diversificação da atividade econômica em exame sejam potencialmente positivos, como o aumento da qualidade e da eficiência produzido pelo regime de competição, um eventual descontrole na proliferação de agentes econômicos e veículos prestando este serviço pode gerar efeitos negativos nas condições de mobilidade nas áreas urbanas. O uso intensivo e descontrolado das vias urbanas para o transporte motorizado individual atinge, pelo menos, a qualidade geral do trânsito nas vias públicas, as condições estruturais da malha viária e o mercado de trabalho. Além disso, na condição de tecnologia disruptiva, a atividade tem o potencial de desorganizar significativamente o sistema de transporte individual remunerado de passageiros em operação há décadas, podendo afetar a quantidade de veículos disponíveis, os horários e locais de operação e o valor das tarifas cobradas dos passageiros. Portanto, é de fato necessário que o Poder Público institua algum mecanismo para controlar os agentes econômicos que pretendam atuar no setor de transporte individual remunerado de passageiros.

\footnotetext{
${ }^{30}$ Ver Immanuel Kant. Fundamentação da Metafísica dos Costumes. São Paulo: Editora Barbarolla, 2009.

${ }^{31}$ Art. 182. A política de desenvolvimento urbano, executada pelo Poder Público municipal, conforme diretrizes gerais fixadas em lei, tem por objetivo ordenar o pleno desenvolvimento das funções sociais da cidade e garantir o bem- estar de seus habitantes.

${ }^{32} \mathrm{Art.} 2^{\circ} \mathrm{A}$ política urbana tem por objetivo ordenar o pleno desenvolvimento das funções sociais da cidade e da propriedade urbana, mediante as seguintes diretrizes gerais:

I - garantia do direito a cidades sustentáveis, entendido como o direito à terra urbana, à moradia, ao saneamento ambiental, à infra-estrutura urbana, ao transporte e aos serviços públicos, ao trabalho e ao lazer, para as presentes e futuras gerações;
} 
A par disso, mesmo para atividades econômicas tipicamente privadas, que não se considera em absoluto serem serviços de utilidade pública, é comum a existência de instrumentos públicos de controle de funcionamento da atividade. É o caso das licenças ambientais para a instalação de indústrias e outras atividades potencialmente lesivas ao meio ambiente e das licenças sanitárias para atividades ligadas à saúde e à alimentação. Nesses casos, a iniciativa privada está proibida de iniciar suas operações sem antes comprovar ao órgão público responsável pela fiscalização da área a satisfação das exigências legais e administrativas pertinentes e obter a respectiva licença de operação.

A conclusão que chegamos, portanto, é o Poder Público não apenas tem o poder, mas também tem o dever de instituir algum sistema de regulação de entrada para o exercício da atividade econômica de transporte individual remunerado de passageiros, que valha não apenas para a empresa UBER, mas para qualquer outro agente econômico que utilize o mesmo modelo, baseado em aplicativos para smartphones ou outros sistemas de captação, oferta e intermediação dessa espécie de serviço de utilidade pública.

\section{A COMPETÊNCIA LEGISLATIVA PARA REGULAR O SERVIÇO DE UTILIDADE PÚBLICA DE TRANSPORTE INDIVIDUAL REMUNERADO DE PASSAGEIROS}

A última questão jurídica juris a ser enfrentada concerne à competência legislativa para legislar sobre a regulação do serviço de transporte individual remunerado de passageiros. Cuida-se de questão de extrema relevância, tendo em vista que o artigo 22, XI, da Constituição Federal atribui à União competência legislativa privativa para legislar sobre "trânsito e transporte", preceito que exclui a competência legislativa acerca de qualquer questão envolvendo os dois temas.

Na visão de Daniel Sarmento, expressa no parecer antes referido, o artigo 30, V, da Constituição Federal imputa aos Municípios tão somente a competência de organizar e prestar, direta ou indiretamente, o serviço de "transporte coletivo". ${ }^{33} \mathrm{O}$ serviço de transporte individual não foi expressamente contemplado entre as competências municipais, razão pela qual incidiria a regra de competência legislativa federal do artigo 22, XI, da Constituição Federal. Entretanto, esses argumentos não representam a melhor interpretação do sistema normativo constitucional de repartição de competências legislativas e materiais. Vejamos por quê.

33 Parecer do Prof. Daniel Sarmento disponível em http://s.conjur.com.br/dl/paracer-legalidade-uber.pdf, acessado em 08/03/2016. 
O artigo 30, I, da Constituição Federal, atribui aos Municípios a competência genérica de "legislar sobre assuntos de interesse local". Não parece haver qualquer dúvida de que a gestão urbana é assunto de interesse da urbe, isto é, da cidade, que compõe o Município. Note-se que o artigo 182 da Lei Fundamental prescreve expressamente que "a política de desenvolvimento urbano, executada pelo Poder Público municipal, conforme diretrizes gerais fixadas em lei, tem por objetivo o pleno desenvolvimento das funções sociais da cidade e garantir o bem-estar de seus habitantes".

Ou seja, a Constituição Federal confere ao Município o protagonismo absoluto na condução da política de desenvolvimento urbano para garantir as funções sociais da cidade. É evidente que a política de mobilidade urbana está incluída na política de desenvolvimento urbano necessária para garantir as funções sociais da cidade. Aliás, é o próprio artigo 10 da Lei n. $12.587 / 2012$ que deixa clara essa relação entre desenvolvimento urbano e mobilidade urbana no âmbito do Município. ${ }^{34}$

Isso explica porque a Constituição Federal, apesar de atribuir à União a competência legislativa para legislar sobre trânsito e transporte, excepciona essa regra para deferir aos Municípios a competência para organizar o serviço de transporte coletivo urbano, competência que claramente envolve legislar sobre essa modalidade de serviço. O serviço de transporte coletivo é assunto de interesse local, afetado à política de desenvolvimento urbano, que, no sistema constitucional, é matéria protagonizada pelos Municípios.

Pois bem, se a atividade econômica de transporte individual remunerado de passageiros é uma espécie de serviço de utilidade pública, seja pela própria natureza da atividade, seja pela dicção expressa do artigo 12 da Lei n. 12.586/2012, algum dos entes federados deverá ter competência legislativa para regular o exercício desse serviço, já que é característica essencial dos serviços de utilidade pública que eles sejam regulados pelo Poder Público. E qual dos entes federados estaria investido dessa competência? Não existe nenhuma norma constitucional expressa que possa oferecer uma resposta inquestionável. Qualquer solução depende de uma interpretação do conjunto de normas que compõem o sistema constitucional.

De acordo com os argumentos expostos acima, a melhor interpretação é a que reconhece aos Municípios a competência legislativa para regular o serviço de utilidade pública de transporte

\footnotetext{
${ }^{34}$ Art. $1^{\circ}$ A Política Nacional de Mobilidade Urbana é instrumento da política de desenvolvimento urbano de que tratam o inciso XX do art. 21 e o art. 182 da Constituição Federal, objetivando a integração entre os diferentes modos de transporte e a melhoria da acessibilidade e mobilidade das pessoas e cargas no território do Município.
}

Revista de Direito da Cidade, vol. 08, no 2. ISSN 2317-7721 pp.775-812 808 
individual remunerado de passageiros, tanto em relação ao modal convencional do táxi (como, aliás, sempre ocorreu no país) quanto em relação a novas modalidades de serviço, como o modelo empregado pela empresa UBER. Como dissemos, os modos, serviços e infraestruturas do transporte urbano, coletivo ou individual, são elementos que compõem o núcleo da política de mobilidade urbana, que, por sua vez, pertencem à macropolítica de desenvolvimento urbano, cujo protagonismo o artigo 182 da Constituição Federal atribuiu aos Municípios.

A atuação legislativa municipal pode se submeter a normas gerais de desenvolvimento urbano instituídas pela União, de que são exemplos a Lei n. 10.257/2001 (Estatuto da Cidade) e a própria Lei n. 12.587/2012. Não parece haver vedação constitucional a que a União aprove lei regulamentando procedimentos de regulação de entrada para serviços de transporte individual remunerado de passageiros, inclusive mediante alteração na Lei n. 12.587/2012. Mas, inexistindo norma federal geral acerca do tema, a melhor resposta jurídica à questão é a que reconhece a competência legislativa municipal para instituir mecanismo de controle ou regulação de entrada de agentes econômicos no serviço de utilidade pública de transporte individual remunerado de passageiros.

\section{CONCLUSÃO}

O ensaio procurou demonstrar a complexidade jurídica da questão que envolve a legalidade do serviço de transporte de passageiros exercido por meio do modelo criado pela empresa UBER, que rapidamente se tornou um case internacional de política de mobilidade urbana e que se revela um difícil caso de interpretação do sistema jurídico brasileiro. Os argumentos jurídicos expostos neste ensaio nos permitiram extrair as seguintes conclusões, que propomos à comunidade jurídica como a melhor interpretação dogmática das normas jurídicas que incidem no problema examinado:

1. O transporte individual remunerado de passageiros é uma atividade econômica que o artigo 12 da Lei n. 12.587/2012 classificou como serviço de utilidade pública. O artigo 12 da lei previu o gênero do serviço de transporte público individual e remunerado de passageiros e o artigo 12-A previu uma de suas espécies, o serviço de táxi. O artigo 12, associado ao direito fundamental à liberdade econômica, previsto no artigo 170, parágrafo único, da Constituição Federal, permite que se deduza a existência de uma norma jurídica não expressa que permite o exercício de outras espécies de serviço público de transporte individual remunerado de passageiros, além do serviço de táxi; 
2. O artigo $2^{\circ}$ da Lei n. $12.468 / 2011$, que torna privativa dos taxistas a prestação de transporte público individual de passageiros, só é compatível com o artigo 5o, XIII, da Constituição Federal, se o submetermos a uma redução teleológica, de modo a limitarmos a incidência do monopólio concedido aos taxistas ao próprio modal táxi. A atividade econômica de transporte público individual de passageiros, na qualidade de serviço de utilidade pública, não é limitada aos profissionais taxistas;

3. Os serviços de transporte individual remunerado de passageiros prestados por meio do modelo da empresa UBER configuram atividade econômica classificada como serviço de utilidade pública. Na condição de atividade econômica, pode ser exercida por meio da UBER, Porém, na qualidade de serviço de utilidade público pode e deve ser objeto de regulação e controle por parte do Poder Público competente;

4. Na regulação da atividade, o Poder Público pode exigir habilitação profissional dos motoristas de veículos automotores que prestarão o serviço de transporte por meio da UBER, curso de formação específica para condução de veículos na prestação do serviço de transporte público individual de passageiros e controlar sua vida criminal pregressa, instituir requisitos em relação ao tipo de veículo a ser utilizado na prestação do serviço, especialmente em relação à data de fabricação e as condições de segurança, conforto e higiene do veículo, a contratação de seguro para cobertura de acidentes, além do seguro obrigatório;

5. O Poder Público pode fixar tarifas máximas a serem cobradas dos usuários e para fiscalizar a cobrança de tarifas abusivas por parte dos prestadores de serviço;

6. O Poder Público pode estabelecer regras e procedimentos para suspender o direito dos motoristas prestadores do serviço de atuarem no transporte público individual sempre que eles ou seus veículos estejam em desacordo com as diretrizes definidas nos itens anteriores.

7. Os Municípios detém competência legislativa para regular o serviço de utilidade pública de transporte individual remunerado de passageiros, tanto em relação ao modal convencional do táxi quanto em relação a novas modalidades de serviço, como o modelo empregado pela empresa UBER.

Como se pode observar, esse conjunto de conclusões limita-se a propor a melhor interpretação das normas jurídicas que incidem sobre o problema jurídico examinado no estudo. Muitos outros aspectos de extrema relevância para a compreensão global do problema e para o 
futuro da mobilidade urbana merecem igual atenção, como os impactos positivos e negativos no sistema tradicional de táxi, no cotidiano dos usuários de transporte individual remunerado, na infraestrutura viária e no mercado de trabalho. Entretanto, a premissa básica adotada pelo estudo está em que o primeiro problema a ser resolvido é a compatibilidade do modelo criado pela empresa com o sistema jurídico brasileiro. Definidos os contornos jurídicos em que esse novo serviço pode operar, as diversas áreas que estudam e atuam no planejamento urbano devem se concentrar em ajustar o serviço à concretização do princípio da cidade sustentável contemplado na Constituição Federal de 1988.

\section{REFERÊNCIAS BIBLIOGRÁFICAS}

BINENBOJM, Gustavo. Transformações do Poder de Polícia: Aspectos Político-Jurídicos, Econômicos e Institucionais. Rio de Janeiro. Tese apresentada no concurso público para Professor Titular de Direito Administrativo na UERJ, 2015.

BRENNER, Neil, MARCUSE, Peter e MAYER, Margit (editors). Cities for People, Not for Profit: Critical Urban Theories and the Right to the City, New York: Routledge, 2012.

CATÃO, Marconi do Ó Catão. Civilizações Urbanas e Teorias da Cidade, Revista de Direito da Cidade, vol. 07, n. 01, p. 91-140.

COPI, Irving M. Copi e COHEN, Carol Cohen. Introduction to Logic. 10ª edição. Editora Prentice Hall, 1998.

DI PIETRO, Maria Sylvia Zanella. Direito Administrativo. 26ạ edição. São Paulo: Editora Atlas, 2004.

DIMOULIS, Dimitri e MARTINS, Leonardo. Teoria Geral dos Direitos Fundamentais. 4a edição. São Paulo: Editora Atlas.

FAINSTEIN, Susan. The Just City, Ithaca: Cornell University Press, 2011.

JUSTEN FILHO, Marçal. Curso de Direito Administrativo. São Paulo: Editora Saraiva, 2005.

FUKUYAMA, Francis. The Origins of Political Order: From Prehuman Times to French Revolution. New York: Farrar, Straus and Giroux, 2012.

GASPARINI, Diógenes. Direito Administrativo. 13a edição. São Paulo: Editora Saraiva, p. 293.

GIACOMUZZI, José Guilherme Giacomuzzi. "O serviço de táxi é serviço público? Em torno de conceitos e da esquizofrenia no direito administrativo brasileiro". Porto Alegre, inédito, 2016. 
GOMES CANOTILHO, José Joaquim. Parecer. Disponível http://saopaulo.estadao.com.br/blogs/bruno-ribeiro/wp-content/uploads/sites/281/2015/12/parecercanotilho-uber.pdf. Acessado em 08/03/2016

GORDILLO, Agustín. Tratado de Derecho Administrativo. Tomo II. Belo Horizonte: Editora Del Rey, 2003.

GUASTINI. Riccardo. Interpretare e Argumentare. Milão: Giuffré Editora, 2011.

KANT, Immanuel. Fundamentação da Metafísica dos Costumes. São Paulo: Editora Barbarolla, 2009.

MAFFINI, Rafael Maffini. Direito Administrativo. 3a edição. São Paulo: Editora RT, 2009.

MEIRELLES, Hely Lopes Meirelles. Direito Administrativo Brasileiro. 33a edição. São Paulo: Editora Malheiros, 2007.

MELLO, Celso Antônio Bandeira de. Curso de Direito Administrativo. 16a edição. São Paulo: Editora Malheiros, 2003.

MITCHELL, Don. The Right to the City: Social Justice and the Fight for Public Space, New York: The Guilford Press, 2003.

SARLET, Ingo Wolfgang, MITIDIERO, Daniel e MARINONI, Luiz Guilherme. Curso de Direito Constitucional. 2o edição. São Paulo: Editora RT.

TAVARES, André Ramos. Parecer. Disponível em http://static1.squarespace.com/static/565cd127e4b09e25856aOfcc/t/5665e22ed8af1088bcd489d 3/1449517614071/Doc+1.pdf. Acessado em 08.03.2016.

Trabalho enviado em 15 de março de 2016.

Aceito em 15 de março de 2016. 